\title{
PENDEKATAN POSITIVE DEVIANCE DALAM UPAYA PENINGKATAN TINGKAT KEHADIRAN SASARAN POSYANDU
}

\author{
Positive deviance Approach for Attendance Improvement of Integrated Health Post Target \\ Risda Monica ${ }^{1}$, Arwa Inas Shafiya ${ }^{2}$, Vidian Imam Nurfadilah ${ }^{3}$, Intan $\mathrm{Hafiza}^{4}$, Hanang Krisnadi ${ }^{5}$, Naufal \\ Muharam Nurdin 6 \\ ${ }^{1-5}$ Mahasiswa Institut Pertanian Bogor, Bogor 16680 \\ ${ }^{6}$ Staf Pengajar Departemen Gizi Masyarakat, Fakultas Ekologi Manusia, IPB, Bogor 16680
}

\begin{abstract}
ABSTRAK
Masalah utama posyandu yaitu rendahnya tingkat kehadiran masyarakat dan sumber daya yang terbatas. Pendekatan positive deviance (PD) merupakan salah satu solusi masalah tersebut. Tujuan penelitian ini adalah untuk menganalisis perilaku positif khusus melalui pendekatan PD serta membuktikan bahwa perilaku positif khusus yang ditemukan dapat diterapkan pada posyandu lain. Penelitian ini adalah penelitian kualitatif observasional untuk menemukan perilaku positif khusus pada posyandu dengan kinerja terbaik dan melakukan intervensi dengan menerapkan perilaku positif tersebut pada posyandu dengan kinerja terburuk. Pengambilan data penelitian ini menggunakan focus group discussion (FGD) terhadap 10 ketua kader posyandu, wawancara mendalam terhadap 59 subjek terdiri atas bidan desa, kader, dan sasaran posyandu di seluruh posyandu (Tunas Harapan, TH 1-10) Desa Sadeng, Kecamatan Leuwisadeng, Kabupaten Bogor serta dilengkapi dengan data sekunder dari laporan bulanan posyandu. Data dianalisis secara kualitatif dengan menggunakan metode pendekatan PD yang terdiri dari lima langkah dasar. Rata-rata kehadiran sasaran posyandu rendah (30,3\%). Hasil penelitian menunjukkan Posyandu TH 6 ditetapkan menjadi model (pelaku) PD. Perilaku positif khusus yang ditemukan meliputi manajemen pembagian tugas kader yang baik, perilaku gotong royong, partisipasi anggota keluarga kader sebagai sukarelawan transportasi kesehatan, kerja sama dengan pendidikan anak usia dini (PAUD), keterlibatan pihak RT, serta bangunan posyandu yang memadai. Sebagian perilaku positif khusus tersebut selanjutnya diterapkan pada Posyandu TH 4 yang memiliki kriteria terburuk dan berhasil meningkatkan kehadiran sasaran dari 23\% menjadi $62 \%$ serta dilakukan pemantauan yang hasilnya meningkat menjadi $70 \%$. Pada penelitian ini pelaku PD dan perilaku positif telah teridentifikasi melalui pendekatan PD serta perilaku tersebut berhasil diterapkan pada posyandu lain.
\end{abstract}

Kata kunci: positive deviance, posyandu, tingkat kehadiran

\begin{abstract}
The main problem of integrated health post is the lack of community participation, and its resources. One of the alternative solution is finding a special behavior with positive deviance (PD) approach. The aim of this research was to analyze positive behavior through PD approach. This research was a qualitative research. The research method was focus group discussion with all cadre leader and indepth interview technique to 59 subjects, village midwife, cadre, and posyandu target in 10 posyandu (Tunas Harapan-TH 1 to 10) at Sadeng Village, Leuwisadeng sub district, Bogor District and completed with secondary data from monthly report of posyandu. These data were analyzed qualitatively using five basic steps in PD approach. The average attendance posyandu target was low (30.3\%). The result showed Posyandu TH 6 is defined as a model (performer) of PD. Specific positive behaviors encountered include better management of task distribution, mutual assistance behavior, cadres family members participation as transport volunteer, cooperation with early childhood education (ECE), sub-village involvement, and adequate posyandu building. These behaviors were applied to the Posyandu TH 4 who had the worst performance and successfully increased its attendance from $23 \%$ to $62 \%$. In this research the PD performer and its positive behavior have been identified through the PD approach and those behaviors were successfully applied to other posyandu.
\end{abstract}

Keywords: positive deviance, posyandu, participation 


\section{PENDAHULUAN}

Posyandu merupakan salah satu bentuk upaya kesehatan berbasis masyarakat (UKBM) guna memberikan kemudahan kepada masyarakat dalam memperoleh pelayanan kesehatan atau sosial dasar untuk mempercepat penurunan angka kematian ibu dan bayi (Dinas Kesehatan Jawa Barat, 2013). Jumlah posyandu yang aktif di Kabupaten Bogor sebanyak 878 dari 4492 unit atau sebesar $20 \%$. Penyebab tersebut dilatarbelakangi oleh kurangnya partisipasi masyarakat, kurangnya sumber daya manusia yang kompeten, serta kurangnya manajemen pengelolaan posyandu. Kementerian Kesehatan RI (2008) memublikasikan data statistik yang menunjukkan bahwa $62,5 \%$ rumah tangga tidak memanfaatkan posyandu karena tidak mengetahui manfaat posyandu, sehingga tidak merasa membutuhkan. Padahal, posyandu sangat penting untuk memperoleh pelayanan kesehatan dasar serta bantuan secara profesional dalam pemecahan masalah kesehatan ibu dan anak (Departemen Kesehatan RI, 2006). Posyandu juga berperan dalam peningkatan status gizi anak guna meningkatkan kualitas sumber daya manusia Indonesia. Penelitian Madanijah dan Triana (2007) melaporkan terdapat korelasi antara tingkat kehadiran posyandu yang tinggi dengan status gizi anak.

Pemerintah telah mencanangkan program Keluarga Sadar Gizi (KADARZI) melalui posyandu, namun belum mampu meningkatkan partisipasi posyandu secara siginifikan (Ocbrianto, 2012). Poin utama dalam revitalisasi posyandu adalah peningkatan jumlah kunjungan posyandu. Peningkatan jumlah kunjungan posyandu akan meningkatkan fasilitas layanan di posyandu yang bersangkutan, sehingga perlu terjadi peningkatan jumlah kunjungan posyandu. Sistem yang diterapkan di posyandu saat ini masih menggunakan pendekatan secara umum tanpa melihat faktor spesifik pada masyarakat. Oleh karena itu, perlu dilakukan strategi yang tepat untuk meningkatkan kinerja posyandu serta partisipasi masyarakat dalam mengikuti kegiatan posyandu berdasarkan karakteristik sosial dan demografis lokasi posyandu. Alternatif solusi masalah tersebut dapat dilakukan dengan penelitian menggunakan pendekatan positive deviance.
Positive deviance (PD) adalah suatu pendekatan terhadap perubahan perilaku dan sosial, berdasarkan pengamatan bahwa pemecahan masalah yang dihadapi masyarakat pada prinsipnya telah ada dalam masyarakat itu sendiri. Tahun 1990, seorang peneliti bernama Jerry Sternin mengurangi tingginya angka balita gizi buruk di Vietnam. Pengujian ini dilatarbelakangi oleh tidak berhasilnya solusi yang diterapkan oleh pemerintah Vietnam berupa perbaikan sistem sanitasi yang buruk, pola distribusi makanan, kemiskinan, dan buruknya akses terhadap air bersih. Sternin menerapkan pendekatan positive deviance untuk mencari perilaku positif keluarga yang sama-sama memiliki sumber daya terbatas, namun memiliki anak dengan status gizi yang baik. Perilaku positif tersebut disosialisasikan dan diterapkan pada keluarga yang memiliki anak dengan gizi buruk. Setahun pertama, lebih dari 1000 anak balita dilibatkan dan berhasil mengurangi angka gizi buruk hingga $80 \%$ (Sternin, 2007).

Pendekatan PD terus dikembangkan dan diadopsi oleh berbagai bidang dan organisasi. Perilaku positive deviance telah berhasil menurunkan 19,1\% balita gizi buruk di Cianjur (Aryastami, 2006), dan mengubah perilaku konsumsi masyarakat Bangladesh menjadi lebih baik (Parvanta dan Sultana, 1998). Penelitian Sab'atmaja, et al. (2010) mengidentifikasi bahwa perilaku positif berupa pola asuh ibu yang baik dapat menunjukkan status gizi anak yang baik di antara anak lainnya di wilayah miskin dengan prevalensi kurang gizi rendah dan tinggi. Selain masalah gizi buruk, PD telah berhasil memberikan solusi yang tepat terkait berbagai masalah kesehatan dan sosial pada masyarakat, serta diadopsi oleh Departemen Kesehatan, PBB, LSM lokal dan internasional di 45 negara di berbagai benua. Saat ini pendekatan PD telah diakukan menjadi sistem lima langkah yang terdiri dari define, determine, discover, design, monitor (Positive deviance Initiative, 2012).

Tujuan utama penelitian ini adalah mencari perilaku positif kader posyandu melalui metode PD dalam rangka meningkatkan jumlah kehadiran masyarakat terhadap posyandu. Tujuan khusus pada penelitian ini yaitu mengidentifikasi tingkat kehadiran masyarakat di 10 Posyandu di Desa 
Sadeng, Kecamatan Leuwisadeng, Kabupaten Bogor, menganalisis perilaku positif yang terdapat di Posyandu Desa Sadeng melalui pendekatan positive deviance serta melakukan intervensi terhadap penemuan perilaku positif terhadap posyandu lain.

\section{METODE}

\section{Desain, Lokasi, dan Waktu}

Penelitian ini adalah penelitian kualitatif observasional dengan pendekatan positive deviance untuk menemukan perilaku positif khusus pada posyandu dengan kinerja terbaik dan melakukan intervensi dengan menerapkan perilaku positif yang ditemukan pada posyandu dengan kinerja terburuk. Kinerja posyandu dinilai dari jumlah dan persentase kehadiran sasaran posyandu. Penelitian dilakukan di seluruh Posyandu Tunas Harapan Desa Sadeng, Kecamatan Leuwisadeng, Kabupaten Bogor, Jawa Barat yang berjumlah 10 posyandu yaitu Posyandu Tunas Harapan (TH) 1 sampai 10. Penelitian ini dilakukan pada bulan Maret sampai dengan Juli 2017.

\section{Cara Pemilihan Subjek}

Populasi dalam penelitian ini adalah seluruh Posyandu Desa Sadeng yang berjumlah 10 Posyandu. Unit sampel penelitian ini yaitu Posyandu Tunas Harapan 1 sampai dengan 10 di Desa Sadeng. Penelitian ini melibatkan seluruh posyandu di Desa Sadeng. Setiap posyandu dilakukan wawancara mendalam terhadap 1 orang ketua dan 1 orang anggota kader serta 3 sampai dengan 4 orang sasaran posyandu. Sasaran atau pengguna posyandu adalah seluruh masyarakat utamanya ibu bayi dan balita, ibu hamil, ibu nifas, dan ibu menyusui (Departemen Kesehatan RI, 2006). Subjek yang diwawancarai disajikan pada Tabel 1.

\section{Metode Pengumpulan Data}

Data yang digunakan dalam penelitian ini meliputi data primer dan data sekunder. Pengumpulan data primer dilakukan dengan cara focus group discussion (FGD) terhadap 10 ketua kader posyandu, wawancara mendalam terhadap 59 subjek terdiri atas bidan desa, kader, dan sasaran posyandu dan observasi langsung di 10 Posyandu Desa Sadeng (Tabel 1).

Wawancara dilakukan untuk mendapatkan data karakteristik subjek, perilaku kader terhadap posyandu, serta perilaku dan sudut pandang sasaran (pengguna) terhadap posyandu. Focus group discussion (FGD) dilakukan pada keseluruhan ketua kader posyandu Tunas Harapan Desa Sadeng untuk mendapatkan data penjabaran masalah posyandu dan mendapat referensi data untuk menentukan perilaku positive deviance. Data sekunder didapatkan dari Laporan Bulanan Posyandu Desa Sadeng 2016-2017 untuk mendapatkan data kehadiran dan karakteristik setiap posyandu di Desa Sadeng.

\section{Metode Penelitian}

Metode penelitian yang digunakan bersifat kualitatif. Analisis data menggunakan pendekatan positive deviance berdasarkan pada Panduan Dasar Lapangan Pendekatan Positive deviance (Positive deviance Initiative, 2012). Pendekatan ini dari lima langkah dasar.

Tahap pertama adalah define, yaitu menjabarkan masalah yang ada di posyandu Tunas

Tabel 1. Subjek Penelitian

\begin{tabular}{|c|c|c|}
\hline Subjek & Kriteria & Jumlah (Orang) \\
\hline Bidan desa & Bidan yang terlibat dalam posyandu & 1 \\
\hline \multirow[t]{2}{*}{ Kader } & Ketua & 10 \\
\hline & Anggota & 10 \\
\hline \multirow[t]{2}{*}{ Sasaran posyandu } & Tidak pernah atau jarang (hadir kurang dari 8 kali per tahun)* & 20 \\
\hline & Sering (hadir lebih dari 8 kali per tahun)* & 18 \\
\hline Total & & 59 \\
\hline
\end{tabular}

*Departemen Kesehatan RI (2006) 
Harapan 1 sampai dengan 10. Tahap ini dilakukan observasi lokasi dan kegiatan posyandu bersama ketua dan anggota kader masing-masing posyandu, selanjutnya dilakukan wawancara mendalam terhadap bidan desa, ketua kader, anggota kader posyandu dan sasaran atau pengguna posyandu. Selanjutnya data primer dan sekunder dari Laporan Bulanan Posyandu Desa Sadeng 2016/2017 diolah.

Tahap kedua adalah determine atau menentukan pelaku PD. Pelaku PD adalah individu atau komunitas yang menunjukkan perilaku positif sehingga orang atau kelompok tersebut dapat mengatasi masalah yang ada di masyarakat dengan kondisi sumber daya dan demografis yang sama (Positive deviance Initiative, 2012). Tahap ini dilakukan observasi berupa survey lokasi dan wawancara terhadap kader dan sasaran posyandu di 10 posyandu di Desa Sadeng. Lalu menentukan posyandu yang dijadikan model pelaku PD.

Tahap ketiga adalah discover, yaitu menemukan strategi khusus atau perilaku positif dari pelaku PD. Tahap ini dilakukan berdasarkan analisis wawancara mendalam dengan bidan, kader dan sasaran posyandu serta focus group discussion (FGD) dengan Ketua Kader Posyandu Tunas Harapan 1 sampai dengan 10.

Tahap keempat adalah design atau merancang kegiatan untuk menerapkan strategi khusus yang telah diidentifikasi sebelumnya. Perilaku positif khusus yang ditemukan diterapkan pada posyandu dengan kinerja terburuk. Pada tahap ini yaitu melakukan intervensi pada posyandu dengan kinerja terburuk dengan cara menerapkan perilaku positif khusus yang ditemukan untuk membuktikan apakah perilaku khusus tersebut dapat diterapkan pada posyandu lain dalam rangka meningkatkan kinerja posyandu tersebut. Intervensi dilakukan pada tanggal 3 Juli 2017 sampai dengan 20 Juli 2017. Intervensi berupa pelatihan dan FGD sebanyak 2 kali pada kader posyandu sasaran.

Tahap kelima adalah monitor atau pemantauan hasil intervensi setelah penerapan perilaku positif khusus pada posyandu yang diintervensi.

\section{HASIL DAN PEMBAHASAN}

\section{Identifikasi Masalah Posyandu di Desa Sadeng}

Desa Sadeng memiliki 10 posyandu dengan berbagai tingkat perkembangan posyandu terdiri dari 5 posyandu pratama, 4 posyandu madya, dan 1 posyandu purnama (Tabel 2). Permasalahan utama posyandu di Desa Sadeng adalah kurangnya kehadiran sasaran posyandu. Rata-rata tingkat kehadiran sasaran posyandu di Desa Sadeng sebesar $30,3 \%$. Jumlah kehadiran tertinggi adalah Posyandu Tunas Harapan 6 sebanyak 136 orang tiap bulan. Persentase kehadiran tertinggi

Tabel 2. Rincian Tingkat Perkembangan dan Kehadiran pada Posyandu di Desa Sadeng, Kabupaten Bogor periode 2016/2017

\begin{tabular}{|c|c|c|c|}
\hline Kelompok Posyandu & Tingkat Perkembangan* & $\begin{array}{c}\text { Sasaran Kehadiran } \\
\text { (Orang/bulan)** }\end{array}$ & $\begin{array}{c}\text { Persentase } \\
\text { Kehadiran** }\end{array}$ \\
\hline Tunas Harapan 1 & Madya & 100 & $33 \%$ \\
\hline Tunas Harapan 2 & Pratama & 123 & $24 \%$ \\
\hline Tunas Harapan 3 & Pratama & 113 & $27 \%$ \\
\hline Tunas Harapan 4 & Madya & 130 & $23 \%$ \\
\hline Tunas Harapan 5 & Madya & 98 & $31 \%$ \\
\hline Tunas Harapan 6 & Purnama & 136 & $37 \%$ \\
\hline Tunas Harapan 7 & Pratama & 115 & $26 \%$ \\
\hline Tunas Harapan 8 & Pratama & 38 & $53 \%$ \\
\hline Tunas Harapan 9 & Pratama & 87 & $34 \%$ \\
\hline Tunas Harapan 10 & Madya & 56 & $36 \%$ \\
\hline Posyandu Desa Sadeng & & 996 & $30,3 \%$ \\
\hline
\end{tabular}

* $\quad$ Berdasarkan kriteria Departemen Kesehatan RI (2006)

** data dari Pemerintah Desa Sadeng (2017) 
adalah Posyandu TH 8 sebesar 53\% sedangkan persentase kehadiran terendah adalah posyandu TH 4. Secara lengkap dapat dilihat pada Tabel 2. Angka ini menunjukkan program yang dicapai posyandu rendah. Menurut Ocbrianto (2012), tingkat kehadiran posyandu di bawah 50\% menunjukkan target capaian program posyandu rendah. Kehadiran yang rendah dapat dipengaruhi berbagai faktor seperti sarana prasarana, tingkat pengetahuan kader, kemampuan petugas untuk memantau pertumbuhan dan konseling, tingkat pemahaman keluarga dan masyarakat tentang posyandu, serta pelaksanaan pembinaan kader (Kementerian Kesehatan RI, 2012).

Hal senada juga didapatkan pada penelitian Nusi (2006) yang menyatakan bahwa aspek-aspek yang memengaruhi kinerja posyandu meliputi kader posyandu, keterlibatan pihak di luar posyandu, dan fasilitas posyandu.

Secara lebih detail penelitian ini juga meneliti tentang penyebab kurangnya minat mengikuti kegiatan posyandu. Pada penelitian ini dilakukan wawancara terhadap sasaran di 10 posyandu Desa Sadeng sejumlah 38 orang (3-4 orang setiap posyandu) yang terbagi menjadi 20 orang yang aktif mengikuti kegiatan posyandu dan 18 orang yang tidak aktif mengikuti kegiatan posyandu.

Alasan terbanyak sasaran posyandu tidak memanfaatkan posyandu adalah adanya isu tentang dampak negatif pemberian imunisasi (11 orang) dan tidak ada pemberian makanan tambahan (10 orang). Secara lebih lengkap dapat dilihat pada Tabel 3.

\section{Penetapan Pelaku Positive Deviance}

Pelaku positive deviance ditetapkan pada Posyandu Tunas Harapan 6, berdasarkan pertimbangan berikut: (1) Perkembangan posyandu sudah mencapai tingkat purnama (baik), padahal umumnya kemampuan finansial dan latar belakang pendidikan masyarakat di sekitarnya tidak jauh berbeda dengan masyarakat lainnya. Umumnya, tingkat pendidikan sasaran (pengguna) posyandu di Desa Sadeng adalah SMP dan pekerjaan ibu sebagai ibu rumah tangga serta suami sebagai buruh. Umur sasaran (pengguna) posyandu umumnya berada pada kisaran $20-29$ dan $30-39$ tahun. Penelitian Idaningsih (2016) menunjukkan bahwa pekerjaan dan umur tidak memengaruhi kunjungan sasaran terhadap posyandu. Lokasi Posyandu Tunas Harapan 6 cukup terpencil dan jauh dari jalan utama $( \pm 10 \mathrm{~km})$.

Pertimbangan kedua, Posyandu Tunas Harapan 6 memiliki jumlah sasaran posyandu terbanyak, yaitu 136 orang dari lima Rukun Tetangga (RT). (3) Persentase kehadiran sasaran Posyandu Tunas Harapan 6 pada periode 2016/2017 termasuk lebih tinggi dibandingkan posyandu lainnya. Jumlah sasarannya tidak jauh berbeda dengan posyandu lainnya, walaupun persentase kehadiran terbanyak pada periode 2016/2017 ada pada posyandu Tunas Harapan 8, namun jumlah sasaran posyandu tersebut lebih sedikit dan lingkup kerjanya pada satu RT saja.

Pertimbangan keempat, Keterlibatan Ketua RT dalam mendukung kegiatan posyandu di lingkup kerja Posyandu Tunas Harapan 6 terbanyak di antara posyandu lainnya. Keterlibatan Ketua RT sebagai tokoh masyarakat berpengaruh terhadap kelancaran program dan kehadiran sasaran posyandu. Ketua RT di Posyandu Tunas Harapan 6 membantu mengumumkan dan mengingatkan pelaksanaan posyandu agar masyarakat hadir ke posyandu. Istri ketua RT turut membantu persiapan

Tabel 3. Alasan Sasaran Posyandu Tidak Memanfaatkan Posyandu

\begin{tabular}{lc}
\hline \multicolumn{1}{c}{ Alasan } & Jumlah Subjek \\
\hline Adanya isu tentang dampak negatif pemberian imunisasi & 11 \\
Tidak ada pemberian makanan tambahan & 10 \\
Tidak memprioritaskan kegiatan posyandu & 8 \\
Penolakan dari anak secara langsung karena takut disuntik & 4 \\
Tidak mengetahui manfaat posyandu & 2 \\
Lainnya & 4 \\
Jumlah & 39 \\
\hline
\end{tabular}

$\mathrm{n}=38$ orang, setiap subjek dapat memilih jawaban lebih dari satu 
Tabel 4. Keterlibatan Tokoh Masyarakat terhadap Posyandu di Desa Sadeng

\begin{tabular}{|c|c|c|c|c|c|c|c|c|c|c|}
\hline Keterlibatan Tokoh Masyarakat & TH 1 & TH 2 & TH 3 & TH 4 & TH 5 & TH 6 & TH 7 & TH 8 & TH 9 & TH 10 \\
\hline $\begin{array}{l}\text { Mengingatkan masyarakat untuk hadir ke } \\
\text { posyandu }\end{array}$ & & & $\sqrt{ }$ & & & $\sqrt{ }$ & & $\sqrt{ }$ & & \\
\hline Mengumumkan informasi posyandu & $\sqrt{ }$ & $\sqrt{ }$ & & $\sqrt{ }$ & $\sqrt{ }$ & $\sqrt{ }$ & $\sqrt{ }$ & $\sqrt{ }$ & $\sqrt{ }$ & $\sqrt{ }$ \\
\hline $\begin{array}{l}\text { Istri Ketua RT membantu persiapan } \\
\text { posyandu }\end{array}$ & & & & & & $\sqrt{ }$ & & & & \\
\hline Diskusi terkait masalah posyandu & $\sqrt{ }$ & $\sqrt{ }$ & & $\sqrt{ }$ & $\sqrt{ }$ & $\sqrt{ }$ & $\sqrt{ }$ & $\sqrt{ }$ & $\sqrt{ }$ & $\sqrt{ }$ \\
\hline $\begin{array}{l}\text { Terlibat pada kegiatan insidental } \\
\text { posyandu }\end{array}$ & & & & $\sqrt{ }$ & $\sqrt{ }$ & $\sqrt{ }$ & & & $\sqrt{ }$ & \\
\hline
\end{tabular}

Keterangan: TH = Posyandu Tunas Harapan

kegiatan, seperti penyiapan pemberian makanan tambahan (PMT), terlibat dalam kegiatan insidental posyandu seperti pekan imunisasi nasional, serta membantu memberikan penjelasan kepada sasaran (pengguna) posyandu apabila ada isu negatif terkait kegiatan posyandu. Pada posyandu lain, Ketua RT tidak sepenuhnya membantu kegiatan posyandu, sehingga interaksi antara pihak RT dengan kader kurang intens (Tabel 4). Penelitian Yuliana (2013) menunjukkan peran tokoh masyarakat dalam keikutsertaan program berupa penyebaran informasi secara tatap muka berpengaruh nyata terhadap kehadiran masyarakat dalam program tersebut.

Pertimbangan kelima, kinerja Kader Posyandu Tunas Harapan 6 sudah baik. Masyarakat menilai puas terhadap kinerja kader karena terampil dan peduli dengan kesehatan ibu dan anak. Semua Kader Posyandu Tunas Harapan 6 merupakan anggota Pemberdayaan Kesejahteraan Keluarga (PKK) Desa Sadeng. PKK merupakan komunitas dalam melakukan gerakan masyarakat yang lahir karena kebutuhan masyarakat (Rodiah, et al., 2016). Penelitian Suhat dan Hasanah (2014) menunjukkan keikutsertaan kader dalam organisasi lain berpengaruh nyata terhadap keaktifan kader dalam kegiatan posyandu. Masyarakat sasaran posyandu di Desa Sadeng merasa terbantu adanya kader mengenai penyelesaian masalah kesehatan, penyuluhan kesehatan ibu dan anak yang intens, serta pendampingan yang dilakukan kader ketika ada kelahiran bayi. Perilaku ini membuat masyarakat semakin akrab dan interaksi dengan kader semakin tinggi, sehingga masyarakat segan apabila tidak datang ke posyandu (Tabel 5).

\section{Penemuan Perilaku Positif pada Pelaku Positive Deviance}

Program posyandu dijalankan oleh kader yang berasal dari masyarakat lokal, sehingga diharapkan mampu meningkatkan partisipasi masyarakat (Departemen Kesehatan RI, 2006). Perilaku positif yang ditemukan pada Posyandu Tunas Harapan 6 adalah kekerabatan yang kuat. Masyarakat di lingkup kerja Posyandu Tunas Harapan 6 memiliki modal sosial yang baik berupa kekerabatan yang kuat sehingga menciptakan kerja sama yang baik untuk mencapai tujuan yang sama dengan hasil yang optimal. Menurut Aldler dan Kwon (2000) dalam Cahyono (2012) modal sosial merupakan

Tabel 5. Penilaian Sasaran (Pengguna) Posyandu terhadap Kader

\begin{tabular}{|c|c|c|c|c|c|c|c|c|c|c|}
\hline Penilaian Sasaran terhadap Kader & TH 1 & TH 2 & TH 3 & TH 4 & TH 5 & TH 6 & TH 7 & TH 8 & TH 9 & TH 10 \\
\hline $\begin{array}{l}\text { Puas terhadap pelayanan kader di } \\
\text { Posyandu }\end{array}$ & $\sqrt{ }$ & $\sqrt{ }$ & $\sqrt{ }$ & $\sqrt{ }$ & & $\sqrt{ }$ & & $\sqrt{ }$ & $\sqrt{ }$ & \\
\hline $\begin{array}{l}\text { Merasa terbantu terkait masalah } \\
\text { kesehatan }\end{array}$ & $\sqrt{ }$ & $\sqrt{ }$ & & $\sqrt{ }$ & $\sqrt{ }$ & $\sqrt{ }$ & $\sqrt{ }$ & $\sqrt{ }$ & $\sqrt{ }$ & $\sqrt{ }$ \\
\hline Pendampingan kelahiran bayi & & & $\sqrt{ }$ & & & $\sqrt{ }$ & & & & \\
\hline $\begin{array}{l}\text { Penyuluhan terkait kesehatan ibu } \\
\text { dan anak diluar posyandu }\end{array}$ & & & & $\sqrt{ }$ & $\sqrt{ }$ & $\sqrt{ }$ & $\sqrt{ }$ & $\sqrt{ }$ & $\sqrt{ }$ & \\
\hline
\end{tabular}

Keterangan: TH = Posyandu Tunas Harapan 
gambaran dari keterikatan internal yang mewarnai struktur kolektif dan memberikan kohesifitas dan keuntungan-keuntungan bersama dari proses dinamika sosial yang terjadi di masyarakat. Modal sosial ini melahirkan perilaku positif yang berhubungan dengan tingkat kehadiran posyandu. Menurut Fukuyama (1999) dalam Cahyono (2012) modal sosial dapat membangun sikap saling percaya antar sesama warga.

Kekerabatan kuat yang ditemukan pada lingkup kerja Posyandu Tunas Harapan 6 adalah adanya manajemen sederhana yang lebih baik terkait pembagian tugas antar kader. Bentuk dari manajemen sederhana ini adalah setiap kader bertanggung jawab terhadap satu RT. Pembagian tugas yang dilakukan berupa pengawasan terhadap kesehatan ibu dan anak, pencatatan rutin terkait jumlah kelahiran dan kehamilan, penyelesaian masalah terkait posyandu, serta penyebaran informasi pelaksanaan posyandu, kesehatan ibu dan anak pada setiap masyarakat sasaran posyandu. Pada posyandu lain tidak didapatkan pola manajemen yang baik, kader tidak dibagi tugasnya dengan jelas dan tidak memiliki deskripsi tugas yang jelas, hal ini menyebabkan kinerja kader pada posyandu selain TH 6 kurang maksimal.

Perilaku gotong royong dalam menyiapkan pemberian makanan tambahan (PMT). Kader Posyandu Tunas Harapan 6, menyiapkan PMT bersama. Berbeda dengan kader posyandu lain yang hanya dilakukan oleh satu orang kader bergiliran. Perilaku gotong royong ini membuat kader Posyandu Tunas Harapan 6 memiliki rasa solidaritas yang tinggi. Adanya anggota keluarga kader sebagai sukarelawan transportasi dalam urusan kesehatan. Akses terhadap jalan raya lingkup kerja Posyandu Tunas Harapan 6 sangat jauh, namun suami dari salah satu kader sebagai pengendara ojeg lokal, sehingga kebutuhan kesehatan masyarakat yang membutuhkan transportasi terpenuhi. Hal ini tidak ditemukan pada posyandu yang lain, sehingga warga di sekitar posyandu selain TH 6 tidak merasa butuh untuk mengikuti kegiatan posyandu.

Integrasi lokasi posyandu dengan PAUD sehingga ada tempat bermain anak di lokasi posyandu. Hal ini membuat anak merasa lebih nyaman ketika menunggu giliran dan bersemangat mengikuti posyandu. Hal ini juga tidak didapatkan pada posyandu lainnya, sehingga minat terutama anak-anak untuk datang ke posyandu lebih rendah.

Adanya pihak yang bersedia menyediakan tempat posyandu yang dapat mendukung pelaksanaan kegiatan posyandu. Bangunan posyandu bersih dan jauh dari sumber pencemaran. Bangunan seperti ini memadai untuk menampung para peserta dan efektif dijadikan sebagai tempat pelaksanaan kegiatan posyandu. Pada posyandu yang lain tempatnya kurang memadai karena sering kali memakai halaman salah satu kader dan terdapat beberapa posyandu yang lokasinya berpindah-pindah (posyandu pratama).

Adanya bantuan dari pihak RT dalam pelaksanaan posyandu, seperti istri ketua RT membantu persiapan pembuatan pemberian makanan tambahan (PMT), penyuluhan kesehatan ibu dan anak, dan diskusi terkait masalah posyandu. Pada posyandu lain, walaupun pihak RT terlibat namun tidak seintensif pada posyandu $\mathrm{TH}$ 6 sehingga sosialisasi kegiatan posyandu maupun upaya pelurusan informasi yang salah (misal: efek negatif imunisasi) tidak berjalan efektif.

Walaupun sarana yang terbatas dan lokasi yang paling terpencil dibandingkan dengan posyandu lainnya namun Posyandu TH 6 memiliki kinerja yang paling baik, hal ini sesuai dengan hasil penelitian Simanjuntak (2009) yang mengidentifikasi bahwa karakteristik sosial dan demografis lokasi posyandu membuat tingkat kinerja posyandu berbeda, karena secara langsung berkaitan dengan latar belakang kader dan masyarakat setempat.

\section{Penerapan Strategi dan Pemantauan dari Hasil Penemuan Positive Deviance}

Penerapan strategi atau perilaku positif yang ditemukan di Posyandu Tunas Harapan 6 perlu dibuktikan efektivitasnya terhadap tingkat kehadiran sasaran di posyandu lainnya. Penerapan strategi dari hasil penemuan tersebut dilakukan di Posyandu Tunas Harapan 4, berdasarkan pertimbangan berikut: (1) Perkembangan posyandu tersebut sudah mencapai tingkat madya (menengah) (memiliki jumlah kader yang cukup), (2) Jumlah sasaran posyandu yang relatif sama 
banyaknya dengan pelaku PD (Posyandu Tunas Harapan 6) namun memiliki persentase kehadiran terendah di antara posyandu lainnya, yaitu sebesar $23 \%$.

Pada tahap intervensi, Posyandu Tunas Harapan 4 menerapkan dua dari enam strategi khusus yang ditemukan pada pelaku PD, yaitu: (1) pembagian tanggung jawab per RT pada setiap kader untuk menyebarkan informasi posyandu dan mengajak masyarakat secara langsung agar mengikuti kegiatan posyandu, dibantu oleh masingmasing RT setempat, (2) perilaku gotong royong dalam menyiapkan pemberian makanan tambahan (PMT). Penerapan dua perilaku ini didasarkan pada dampak dari penerapan kedua strategi tersebut dapat dilihat dalam jangka pendek, selain itu perilaku positif lainnya (misal integrasi dengan PAUD, sarana transportasi swadaya) sangat terkait dengan ketersediaan sarana dan prasarana yang tidak mungkin disediakan dalam waktu singkat. Oleh karena itu hanya dari 2 dari 6 perilaku ini yang diterapkan.

Penerapan perilaku ini dilakukan dengan FGD pada kader posyandu TH 4 untuk menentukan pembagian tugas kader dan membagi kader untuk bertanggung jawab per RT. Pelatihan manajemen sederhana ini juga melibatkan RT setempat sehingga setiap kader mengetahui tugas dan tanggungjawabnya serta mampu berkoordinasi dengan RT setempat. Selain itu dilakukan juga pelatihan untuk membuat PMT agar lebih menarik serta mengubah pola pembuatan PMT yang tadinya dilakukan secara individu masingmasing kader secara bergiliran menjadi gotong royong secara bersama-sama di rumah salah satu kader. Pola ini secara efektif meningkatkan rasa kekerabatan dan solidaritas kader yang pada akhirnya meningkatkan kinerja kader. FGD dan pelatihan ini dilakukan selama 2 hari (2 kali pertemuan). Terdapat peningkatan jumlah kehadiran sasaran di Posyandu Tunas Harapan 4 setelah menerapkan dua perilaku positif yang ditemukan pada Posyandu Tunas Harapan 6. Persentase kehadiran sebelum intervensi sebesar $23 \%$, sedangkan setelah dilakukan intervensi naik menjadi 62\% (Tabel 6). Hal ini sesuai dengan penelitian Lorungwa dan Terhemba (2009) bahwa perilaku positif terbukti memberikan solusi yang sebenarnya sudah ada dalam masyarakat tersebut dengan cara mengidentifikasi dan mengoptimalkan sumber daya yang ada.

Pemantauan dilakukan sebulan setelah intervensi. Pemantauan dilakukan untuk membuktikan efektifitas penerapan perilaku yang telah dilakukan. Pada saat intervensi persentase kehadiran $62 \%$, setelah tidak dilakukan intervensi, terdapat peningkatan kehadiran menjadi $70 \%$ (Tabel 6). Peningkatan ini menunjukkan perilaku positif yang diterapkan secara konsisten mampu meningkatkan kehadiran sasaran posyandu.

Penelitian ini telah berhasil menemukan perilaku-perilaku positif berdasarkan pendekatan positive deviance. Perilaku khusus tersebut dapat diterapkan pada posyandu lain serta terbukti meningkatkan tingkat kehadiran sasaran terhadap kegiatan posyandu.

\section{KESIMPULAN}

Posyandu di Desa Sadeng memiliki tiga tingkat perkembangan posyandu, yaitu pratama, madya, dan purnama. Permasalahan utama posyandu yang diidentifikasi adalah rendahnya tingkat kehadiran sasaran posyandu. Pelaku positive deviance ditetapkan pada Posyandu Tunas Harapan 6 yang merupakan posyandu dengan kinerja terbaik. Hasil analisis melalui pendekatan

Tabel 6. Perbandingan Tingkat Kehadiran Sasaran Posyandu Tunas Harapan 4 terkait Penerapan dan Pemantauan Perilaku Positif dari Pelaku Positive Deviance

\begin{tabular}{llll}
\hline \multirow{2}{*}{ Rincian } & \multicolumn{3}{c}{ Data Posyandu Tunas Harapan 4 } \\
\cline { 2 - 4 } & \multicolumn{1}{c}{ Sebelum Intervensi* } & \multicolumn{1}{c}{ Setelah Intervensi } & \multicolumn{1}{c}{ Pemantauan } \\
\hline Jumlah Sasaran & 130 orang & 130 orang & 130 orang \\
Jumlah Kehadiran & 30 orang & 81 orang & 91 orang \\
Persentase Kehadiran & $23 \%$ & $62 \%$ & $70 \%$ \\
\hline
\end{tabular}

* Pemerintah Desa Sadeng (2017) 
positive deviance terdapat enam perilaku positif khusus pada posyandu Tunas Harapan 6 yaitu 1) manajemen pembagian tugas kader yang baik, 2) perilaku gotong royong dalam penyiapan PMT, 3) partisipasi anggota keluarga kader sebagai sukarelawan transportasi kesehatan, 4) kerja sama dengan pendidikan anak usia dini (PAUD), 5) keterlibatan pihak RT, serta 6) bangunan posyandu yang memadai. Hasil penerapan dua dari enam perilaku positif khusus yaitu pelatihan manajemen pembagian tugas kader dan perubahan pola penyiapan PMT secara gotong royong pada Tunas Harapan 4 yang memiliki persentase kehadiran paling rendah, telah berhasil meningkatkan kehadiran secara signifikan. Hasil monitoring juga menunjukkan peningkatan kehadiran tersebut terjadi secara konsisten. Pada penelitian ini pelaku PD dan perilaku positif telah teridentifikasi melalui pendekatan PD serta perilaku tersebut berhasil diterapkan pada posyandu lain.

\section{PERSANTUNAN}

Tim mengucapkan terima kasih kepada Direktorat Pendidikan Tinggi, Kementerian Riset, Teknologi, dan Pendidikan Tinggi yang telah menghibahkan dana untuk pelaksanaan penelitian dalam rangka Program Kreativitas Mahasiswa (PKM). Selain itu, tim juga mengucapkan terima kasih kepada Direktorat Kemahasiswaan IPB, Reviewer Internal dan Eksternal PKM 2017, Masyarakat Desa Sadeng, dan seluruh pihak yang terlibat.

\section{DAFTAR PUSTAKA}

Aryastami, K. (2006). Perbaikan gizi anak balita melalui pendekatan positive deviance: Sebuah uji coba di Kabupaten Cianjur. Puslitbang, 25(2), 67-74.

Cahyono, B. (2012). Peran modal sosial dalam peningkatan kesejahteraan masyarakat petani tembakau di Kabupaten Wonosobo. CBAM, 1(1), 131-144.

Departemen Kesehatan RI. (2006). Pedoman umum pengelolaan posyandu. Jakarta: Depkes RI.

Dinas Kesehatan Provinsi Jawa Barat. (2013). Posyandu di Jawa Barat. Bandung: Dinkes Jawa Barat.
Idaningsih, A. (2016). Faktor-faktor yang berhubungan dengan kunjungan balita ke posyandu. Jurnal Ilmiah Indonesia, 1(2), 16-29. Diakses dari http://jurnal.syntaxliterate.co.id/ index.php/syntax-literate/article/view/26.

Kementerian Kesehatan RI. (2008). Riset kesehatan dasar 2007. Jakarta: Kemenkes RI .

Kementerian Kesehatan RI. (2012). Kinerja kegiatan pembinaan gizi tahun 2011. Jakarta: Kemenkes RI.

Lorungwa, A.S., \& Terhemba, T.L. (2009). Nutritional sustainability via positive deviance: Challenges for teaching, research and extension. Pakistan Journal of Nutrition, 8(10), 17061710. Diakses dari http://agris.fao.org/agrissearch/search.do? recordID=DJ2012054009.

Madanijah, S., \& Triana, N. (2007). Hubungan antara status gizi masa lalu dan partisipasi ibu di posyandu dengan kejadian tuberkulosis pada murid taman kanak-kanak. Jurnal Gizi dan Pangan, 2(1), 29-41. Diakses dari http:// journal.ipb.ac.id/index.php/jgizipangan/article/ view/4400.

Nusi, A. (2006). Analisis kinerja posyandu di Kota Gorontalo di Institut Pertanian Bogor (Skripsi yang tidak dipublikasikan). Institut Pertanian Bogor, Bogor.

Ocbrianto, H. (2012). Partisipasi masyarakat terhadap posyandu dalam upaya pelayanan kesehatan balita di Universitas Indonesia (Skripsi tidak dipublikasikan). Universitas Indonesia, Depok, Indonesia.

Parvanta, C.F., \& Sultana, N. (1998). Final report, Bangladesh nutrition education experimental trial. Washington: International Life Sciences Institute.

Pemerintah Desa Sadeng. (2017). Laporan bulanan posyandu Desa Sadeng Kecamatan Leuwisadeng Kabupaten Bogor Periode 2016/2017. Bogor: Pemerintah Desa Sadeng.

Positive deviance Initiative. (2012). Panduan dasar lapangan pendekatan positive deviance (PD). Boston: PDI.

Rodiah, S., Lusiana, E., \& Agustine, M. (2016). Pemberdayaan kader PKK dalam usaha penyebarluasan informasi kesehatan Jatinangor. Dharmakarya, 5(1), 5-8. Diakses dari jurnal.unpad.ac.id/dharmakarya/article/ download/9923/5238.

Sab'atmaja, S., Khomsan, A., \& Tanziha, I. (2010). Analisis determinan positive deviance status 
gizi balita di wilayah miskin dengan prevalensi kurang gizi rendah dan tinggi. Jurnal Gizi dan Pangan, 5(2), 103-112. Diakses dari https:// www.researchgate.net/publication/277823608 ANALISIS_DETERMINAN_POSITIVE_ DEVIANCE_STATUS_GIZI_BALITA_ DI_WILAYAH_MISKIN_DENGAN_ PRËVALENSI_KÜRANG_GIZZI_RENDAH_DAN_TINGGI.

Simanjuntak, M. (2009). Karakteristik sosial demografi dan faktor pendorong kinerja posyandu. Jurnal Wira Ekonomi Mikroskill, 2(1), 49-58. Diakses dari https://www.mikroskil. ac.id/ejurnal/index.php/jwem/article/view/68.

Sternin, J. (2007). The vietnam story: narrated by Jerry Sternin. Diakses dari http://www.
positivedeviance.org/about_pd/Monique $\% 20$ VIET\%20NAM\%20CHAPTER\%20Oct2017. pdf.

Suhat \& Hasanah, R. (2014). Faktor-faktor yang berhubungan dengan keaktifan kader dalam kegiatan posyandu (studi di Puskesmas Palasari Subang). Jurnal Kesehatan Masyarakat, 10(1), 73-79. Diakses dari https://journal.unnes.ac.id/ artikel_nju/kemas/3072.

Yuliana, E. (2013). Perananan kepala adat dalam sosialisasi program keluarga berencana di Pampang Kelurahan Sungai Siring Samarinda. eJurnal Ilmu Komunikasi, 1(2), 95-108. Diakses dari http://ejournal.ilkom.fisip-unmul. ac.id/site/?p=734. 